\title{
THE SCIENTIFIC CREATIVITY OF FIFTH GRADERS IN A STEM PROJECT-BASED COOPERATIVE LEARNING APPROACH
}

\author{
Nyet Moi Siew, Norjanah Ambo \\ University Malaysia Sabah, Malaysia \\ E-mail: snyetmoi@yahoo.com, norjanah5944@gmail.com
}

\begin{abstract}
This research aimed to examine the effects of an integrated STEM project-based with cooperative learning (STEM-PjBCL) approach on fifth graders' five sub-scales of trait dimension in scientific creativity. A quasiexperimental pre-test and post-test non-equivalent control group design was employed. A total of 360 fifth graders from four randomly selected primary schools were chosen as sample and assigned to STEMPjBCL (n=120), PjBL (n=120), and Conventional (CV) $(n=120)$ instructional methods. The Figural Scientific Creativity Test was used as the pre-test and post-test. Multivariate Analysis of Covariance (MANCOVA) was performed on the post-test scores with pre-test scores as the covariates to examine whether a significant difference existed across the three methods. The results showed that fifth graders taught with the STEM-PjBCL method significantly outperformed their counterparts in the PjBL and CV method in Fluency, Originality, Elaboration, Abstractness of title, and Resistance to premature closure. However, fifth graders taught in the PjBL method did not significantly outperform their counterparts in the $C V$ method in the five sub-scales of scientific creativity. Large effect sizes were obtained for comparing STEM-PjBCL with the PjBL and CV method. The results suggest that the STEM-PjBCL method produces a significant beneficial effect on promoting the five sub-scales of trait dimension of scientific creativity among fifth graders.
\end{abstract}

Keywords: cooperative learning, project-based learning, scientific creativity, STEM, trait dimension.

\section{Introduction}

Creativity is one of the most significant aspects of human capital development as the nation's future depends on creative and innovative citizens. Thus, creativity is emphasized in many areas of study including science education. In science education, creativity refers to scientific creativity (Mukhopadhyay \& Sen, 2013). Sak and Ayas (2013) asserted that it involves a process of interaction between general creativity skills, skills related to science, and scientific knowledge to produce original ideas or products. According to Mukhopadhyay and Sen (2013), it is necessary to develop scientific creativity among students specifically in the context of science learning as students are referred to as "future citizens and potentiality of this important resource influences the progress of the nation significantly" (Mukhopadhyay \& Sen, 2013, p. 1).

The recently revised Malaysian Primary School Standard Curriculum has paid much attention on fostering children's creativity (Curriculum Development Centre, 2014). However, there is little evidence to demonstrate the research conducted on scientific creativity in primary schools. A lack of attention to scientific creativity in the design of effective instruction for primary schools can lead to the decline in creativity among young children. There is some evidence reported by Kim (2011) that the declining creativity levels appear to have been largest in young children. Hence, it is important to investigate specific instruction methods that can contribute to the development of scientific creativity in primary school science lessons. 
PROBLEMS

OF EDUCATION

IN THE $21^{\text {st }}$ CENTURY Vol. 78 , No. 4, 2020

628

Constructionism postulates that individuals learn best when they are creating an artefact that can be reflected upon and shared with others (Harel \& Papert, 1991; Kafai \& Resnick, 1996). Constructionism believes that individuals are most likely to become engaged in learning when they find the artifacts are personally meaningful. Thus, emphasis needs to be given to the technical product, one of the product dimensions in Scientific Creativity Structure Model (SCSM) as developed by Hu and Adey (2002). In this way, students are triggered to exhibit their scientific creativity by designing and creating novel and unique science-based prototypes. The demand for creative development calls for the need of an appropriate instructional method that can guide teachers to foster scientific creativity among children.

\section{Project-Based Learning and Students'Creativity}

Many researchers (Bell et al., 2010; Shriki, 2013) claimed that the use of project-based learning $(\mathrm{PjBL})$ as an instructional method is helpful in enhancing creative thinking. However, Storer (2018) argued that the current literature provides little information that specifically targets the effects of PjBL on students' creativity. Several studies have demonstrated how PjBL experience in designing and making science-based prototypes helps pre-service teachers to foster their creativity (Mayasari et al., 2016; Siew et al., 2015). However, the research which specifically investigated the effects of PjBL on students' scientific creativity at the primary school level is lacking.

Project-based learning $(\mathrm{PjBL})$ is defined as "a teaching method in which students learn by actively engaging in real-world and personally meaningful projects" (The Buck Institute for Education, 2020, p. 1). Holm (2011) further referred PjBL as a "student-centered instruction that occurs over an extended time period, during which students select, plan, investigate and produce a product, presentation or performance that answers a real-world question or responds to an authentic challenge " (Holm, 2011, p. 1). These definitions imply that PjBL focuses learning around real world problems which are authentic, engaging, and challenging. The authentic and challenging nature of these problems, according to English et al. (2017), required students to draw on STEM disciplinary knowledge as they work to design and construct 3-D models. STEM is an approach to interdisciplinary curriculum practices that built around authentic problems which include some or all of the disciplines of science, technology, engineering and mathematics (Tytler et al., 2015).

According to Stylianidou et al. (2018), STEM activities which are based on experimenting and experiential learning are effective ways of developing student creativity. This is supported by Henriksen (2014) who claimed that STEM is one of the most important methods to develop creativity. This is because the interdisciplinary nature of STEM engages students to apply their knowledge from different disciplines such as science, technology, engineering, and mathematics to create a new product. Hence, by integrating STEM disciplines to solve real-life problems via project-based learning has the potential to develop students' scientific creativity (Hanif et al., 2019).

\section{Integrated Approach of STEM with Project-Based Learning and Cooperative Learning}

Researchers (Siew et al., 2015) asserted that PjBL provides a mechanism through which pre-service science teachers can develop their creativity when STEM is integrated in project-based learning. This mechanism encourages learners to use their ideas and skills to consider creative ways of designing and making science-based toys. Mayasari et al. (2016) also highlighted that $\mathrm{PjBL}$ acts as a catalyst to help pre-service physics teachers think creatively by integrating STEM knowledge into making creative products. Thus, utilizing PBL can be an effective way to engage learners in STEM learning and offer them opportunities to be creative. 
Despite the recognized contributions of STEM within project-based learning, the approach remains largely underrepresented for the elementary grades. In order to increase college and career readiness in STEM, it is important that students experience an integrated project-based learning and STEM at the elementary school level.

Despite the importance of group work as a component of learning and teaching in PjBL, Hassanien (2006) claimed that students continue to experience problems in group-related works. Students attribute these problems to the lack of individual accountability. Numbered Heads Together (NHT) is a cooperative learning model that holds each student accountable to learning as a group (Kagan \& Kagan, 2009). NHT was proven effective in fostering learners' scientific creativity (Maulana, 2014; Siew \& Chin, 2018; Steen, 2013). Thus, the researcher has integrated the Numbered Head Together into PjBL and STEM activities to create conducive environments for fostering scientific creativity.

This research thus employed an integrated approach where the element of STEM was incorporated with PjBL and cooperative learning $(\mathrm{CL})$, namely, the STEM project-based with cooperative learning approach (STEM-PjBCL). With this integrated approach, the students were prompted to think creatively about the disciplines of STEM in designing and making technical products as a group via the PjBL process. Fifth graders who are typically 10-11-yearolds were found to have high creativity (Smith \& Carlsson, 1983) and be able to produce unique and unusual ideas (Kim, 2011). Thus, it is hypothesized that the STEM-PjBCL approach may help fifth graders to develop scientific creativity through designing and creating science-based prototypes.

\section{Theoretical Model}

The theoretical model of scientific creativity was based on the Scientific Creativity Structure Model (SCSM) developed by Hu and Adey (2002). Some changes were made to the SCSM to suit the purpose of this research (Figure 1). The revised SCSM was used to guide the development of learning module and test items through three dimensions namely Product, Trait and Process. Technical product was one of the sub-scales chosen in Product dimensions to be measured in this research. According to Hu and Adey (2002), a technical product is a sciencebased prototype that is technologically engineered to execute specific tasks and is subject to innovation. By emphasizing the technical product sub-scale, the children were triggered to use their imagination and thinking in creating several relevant science-based prototypes which are expected to be unique, elaborated, and embellished with an abstract title. 
PROBLEMS

OF EDUCATION

IN THE $21^{\text {st }}$ CENTURY

Vol. 78 , No. 4, 2020

630

Figure 1

The revised scientific creativity structure model

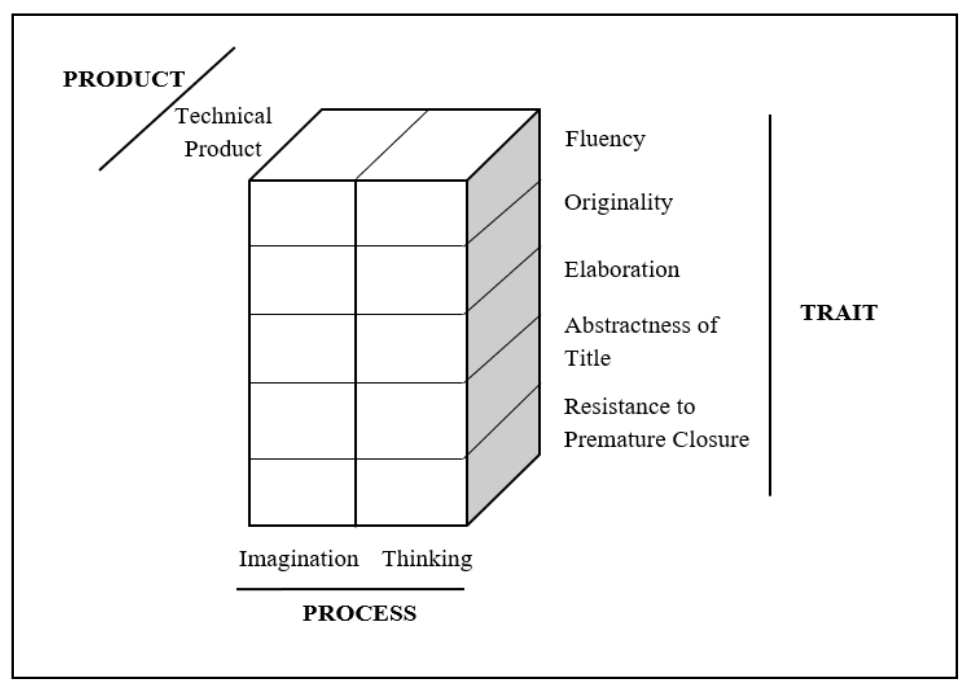

Research Purpose and Hypotheses

Existing empirical studies have shown that taking a project-based approach to STEM learning can help foster creativity in students (Hanif et al., 2019; Siew et al., 2015). However, in these research studies, little is reported on the positive effects of this integrated approach on the trait dimension of scientific creativity at the elementary school level. Therefore, the overall goal of the present research is to determine the extent to which the STEM-PjBCL instructional method would foster the trait dimension of fifth graders' scientific creativity. For the purpose of this research, the sub-scales of trait dimension refer to creative abilities of Torrance et al. (2008) in producing i) a number of ideas a person expresses through interpretable responses that sue the stimulus in a meaningful manner [Fluency (F)]; ii) ideas that are based on the statistical infrequency and unusualness of the response [Originality (O)]; iii) ideas that can be expanded or enriched that go beyond the minimum required [Elaboration (E)]; iv) the essence of the information, enabling the viewer to see the title more deeply and richly [Abstractness of Title (A)]; and v) an openness of mind that considers all available information [Resistance to Premature Closure (R)] (Torrance et al., 2008, p. 5).

In order to determine if other modes of $\mathrm{PjBL}$ were equally effective in producing the desired outcomes, the comparisons between two different forms of the PjBL instructional method, as well as comparisons with the Conventional PjBL instructional method were conducted. Consequently, this research was carried out to determine whether there were any significant differences between learners who were taught under three different instructional methods in the sub-scales of trait dimension of scientific creativity, namely STEM-PjBCL, PjBL and CV method. Accordingly, the following hypotheses were postulated:

1. Fifth graders taught via the STEM-PjBCL instructional method will gain a significantly higher level than their counterparts taught via the PjBL in the five subscales of trait dimension of scientific creativity of i) Fluency, ii) Originality, iii) Elaboration, iv) Abstractness of title, and v) Resistance to premature closure.

2. Fifth graders taught via the STEM-PjBCL instructional method will gain a significantly higher level than their counterparts taught via the $\mathrm{CV}$ in five sub-scales 
of trait dimension of scientific creativity of i) Fluency, ii) Originality, iii) Elaboration,

iv) Abstractness of title, and v) Resistance to premature closure.

3. Fifth graders taught via the PjBL instructional method will gain a significantly higher level than their counterparts taught via the $\mathrm{CV}$ in five sub-scales of trait dimension of scientific creativity of i) Fluency, ii) Originality, iii) Elaboration, iv) Abstractness of title, and v) Resistance to premature closure.

\section{Research Methodology}

\section{Research Design}

A quasi-experimental pre-test and post-test non-equivalent control group design was employed to determine the effects of three different instructional methods on fifth graders' trait dimension of scientific creativity. This research design included assignment, but without the critical feature of random assignment of the subjects to either experimental or the control condition (Seel, 2012). All existing students in the class were taken as respondents of an intact group. Disturbance would arise on the part of schools if students are randomly assigned to the control and experimental groups (Campbell \& Stanley, 1963). Furthermore, this research design is appropriate as it enhances ecological validity (Gill \& Johnson, 2002) in which classes are available in use as intact groups. However, random assignment was used to determine which class would be taught using STEM-PjBCL method (experimental group 1), PjBL method (experimental group 2), or Conventional method (control group). The three separate-sample pre-test-post-test designs controlled all threats to external validity and therefore permit a valid generalization of experimental results to the target population (Seel, 2012). The dependent variables were students' five sub-scales of trait dimension of scientific creativity namely Fluency, Originality, Elaboration, Abstractness of Title, and Resistance to Premature Closure.

\section{Research Sample}

The research population comprised of 4,537 fifth graders from 59 primary schools in Tawau, Sabah, Malaysia (Tawau District Education Office, 2017). This research was carried out in four urban fully government-funded primary schools in Tawau between September and November 2018. The four schools were chosen based on the similar mean score gained by its fifth graders in scientific creativity pre-test. The selection took place over two weeks in September 2018. The four urban schools were chosen to reduce the demographic differences (e.g., school grades, ethnicity, socioeconomic status) among the research samples. Each class typically consists of 30-35 students. Thus, a total of $360 \mathrm{fifth}$ graders were involved as research samples with 120 students selected from each school (Table 1). According to Chua (2012), the minimum sample size appropriate for the experimental research is 30 . 
Nyet Moi SIEW, Norjanah AMBO. The scientific creativity of fifth graders in a STEM project-based cooperative learning approach

PROBLEMS

OF EDUCATION

IN THE $21^{\text {st }}$ CENTURY

Vol. 78, No. 4, 2020

632

Table 1

Distribution of research subjects by school and instructional method

\begin{tabular}{llll}
\hline & \multicolumn{3}{c}{ Instructional method } \\
\cline { 2 - 4 } School & STEM-PjBCL & PjBCL & CV \\
\hline A & 30 & 30 & 30 \\
\hline B & 30 & 30 & 30 \\
\hline C & 30 & 30 & 30 \\
\hline D & 30 & 30 & 30 \\
\hline Total & 120 & 120 & 120 \\
\hline
\end{tabular}

The fifth graders consisted of 193 (54\%) girls and 169 (46\%) boys aged 16 years. The three classes in the chosen schools were randomly assigned to one of the instructional methods as intact groups: the STEM-PjBCL method, PjBL method, or the CV method. According to Seel (2012), several treatments may provide a better explanation for the observed effects. All the instructional methods were followed through by fifth graders over a period of 12 weeks.

\section{Research Instrument}

The Figural Scientific Creativity Test (FSCT) developed by researchers (Ambo \& Siew, 2017) was used as a pre-test and post-test to evaluate the trait dimension of fifth graders' scientific creativity. The FSCT contained six items which were constructed based on the revised Scientific Creativity Structure Model (Figure 1). The test items were scored using the scoring criteria adapted from Torrance et al. (2008). FSCT was a paper-pencil test that measured the students' five sub-scales (fluency, originality, elaboration, abstractness of title, and resistance to premature closure) through their creative imagination and thought process in sketching a technical product. The FSCT items required responses that were mainly sketching and labelling in nature. The students were also required to give a unique name to their sketches.

From the analysis of FSCT's measurement properties, it was found that the discrimination coefficient for all items ranged from 0.22 to 0.36 . The internal consistency in the form of Cronbach's Alpha was 0.77. The item-total correlations ranged from 0.56 to 0.76 . The correlations between assessors ranged from 0.603 to 0.976 . Based on the exploratory factor analysis, FSCT have a total of six items on one factor. Therefore, this indicates that the FSCT instrument was reliable and valid for measuring fifth graders' scientific creativity.

Ten minutes were required to complete each of FSCT items, while 60 minutes were required for answering the FSCT. The FSCT was used as a pre-test in experimental groups and the control group prior to the start of the intervention and as a post-test after the intervention was completed.

\section{The Instructional Methods}

The following sections discuss the differences between the three instructional methods. STEM-PjBCL 
The STEM-PjBCL module developed by researchers (Siew \& Ambo, 2018) was utilized in the STEM-PjBCL instructional method. The STEM-PjBCL module was developed based on the integration of the four phases of the Directed Creative Model (Plsek, 1997), Numbered Heads Together cooperative learning model (Kagan \& Kagan, 2009), engineering design process (Massachusetts Department of Elementary and Secondary Education, 2016) and STEM. PjBL engages learners in four creative phases: Preparation, Imagination, Development, and Action. Students are also engaged in an engineering design process which focuses on solutions by sketching and constructing technical products that drive students to encounter the five subscales of trait dimension of scientific creativity. The STEM-PjBCL module was found to have a moderate high acceptability of fifth graders, good content validity, and acceptable reliability (Siew \& Ambo, 2018).

The STEM-PjBCL module was administered within 12 separate weeks, where 60 minutes were required to complete each of the 12 activities. Teachers acted as facilitators, supervised groups and intervened to offer task assistance when needed.

Students were assigned to heterogeneous group consisting of four members in each group with no bias to different backgrounds (e.g. social variations, gender, and ethnicity). The teacher grouped the students in such a way that each group was inclusive of two low and two high ability members based on their scores in FSCT pre-test. Each student in the STEM-PjBCL group was assigned a certain role as a way to promote individual accountability (Davies, 2009) and was identified by a number (one to four).

Ill structured and real-life problems with no fixed solutions (Jonassen, 1997) were given to students. An example of a real-world problem that provoked group discussion in the project is as below:

Some residents living in squatter areas in Tawau have narrow homes and are less well-lighted. How can you help the residents to illuminate the dark space at cheap and eco-friendly costs? Your group needs to design and make as many home models as you can for persuading the residents to use your idea in building their house in future.

The students put their heads together to come up with the best sketches and technical products. The projects were graded based on a clearly defined rubric. The improvement was made to the technical products based on the integrated knowledge of science, technology, engineering, and mathematics. In this stage, students were engaged to showcase their different, unique, elaborated and completed product with an abstract title.

$\mathrm{PjBL}$

The fifth graders in the PjBL group were exposed solely to PjBL with ill-structured problems as given in STEM-PjBCL group. In solving ill-structured problems, students were required to apply their domain knowledge in a meaningful way (White \& Frederiksen, 1998). They were assigned to group learning with an unstructured group. Fifth graders were given the freedom to choose their group members. As a result, the group members formed by the fifth graders might have different or similar creative abilities. Several studies reported selfselected grouping as positively associated with best team experiences, such as high degrees of cooperativeness, goal commitment and the feeling of group member's indispensability (Bacon et al., 2019; Hilton \& Philips, 2010; Russell, 2010).

In addition, the STEM was not explicitly emphasized during the PjBL activities. The fifth graders were presumed to have knowledge in designing and creating a technical product using prior STEM knowledge. Sketching of prototypes was not carried out in this learning group. 
Nyet Moi SIEW, Norjanah AMBO. The scientific creativity of fifth graders in a STEM project-based cooperative learning approach

\begin{tabular}{r|r} 
PROBLEMS & \\
OF EDUCATION & \\
IN THE 21st CENTURY \\
Vol. 78, No. 4, 2020 \\
\hline 634
\end{tabular}

Fifth graders in the $\mathrm{CV}$ group were taught about projects and group work in a conventional way. Students carried out projects based on well-structured problems pre-planned by teachers. The conventional PjBL was adapted from project approach proposed by Katz (1994) that involved three phases. These phases were i) discussion on solutions to a given well-structured problem, ii) execution of hands-on activities to construct prototypes, and iii) presentation of prototypes.

Students were given freedom to select group members with whom they most preferred to work with. However, the project activities and functioning of the groups were not monitored by the teachers. The fifth graders designed and created technical products after school hours without teacher guidance and team collaboration. As the fifth graders encountered problems during the project activities, they approached their teachers for assistance. Hence, fifth graders in $\mathrm{CV}$ group lacked cooperation as a group as well as missed the opportunity in gaining explicit STEM knowledge to solve an ill-structured problem.

At the end of the intervention in each instructional method, students were asked to individually answer the post-test. Their scores were computed and perceived as an indicator of change in their five sub-scales of trait dimension in scientific creativity.

\section{Data Analysis}

Quantitative data was collected through the pre-test and post-test of the Figural Scientific Creativity Test (FSCT). Descriptive statistics were performed for estimating means and standard deviations. MANOVA was used to analyze the equivalence of the research groups at pre-tests using the scores obtained from pre-test (Pr-F, Pr-O, Pr-E, Pr-A, and Pr-R). In this research, the pre-tests served as covariates for the instructional groups, acting to adjust possible pre-existing differences between the intervention groups.

The main effects of the three different instructional methods on students' post-tests was assessed by using a multivariate analysis of covariance (MANCOVA) while controlling the five covariates. According to Hair et al., (2010), the extraneous differences among groups can be controlled by using MANCOVA after removal of the effects of covariates from the dependent variable. If the overall multivariate test (MANCOVA) was significant, the univariate $\mathrm{F}$ test (ANCOVA) was conducted on post-test mean scores with pre-test mean scores as covariates to further assess if there was a significant statistical main effect of instructional groups on each of post-tests.

In addition, the effect size index (f) and partial eta square $\left(\eta^{2}\right)$ were calculated. Cohen (1988) suggested that the values of $\mathrm{f}<0.2,0.2 \leq \mathrm{f}<0.5,0.5 \leq \mathrm{f}<0.8$, and $\mathrm{f} \geq 0.8$ represent very small, small, medium, and large effect sizes, respectively. Whereas, for interpreting $\eta^{2}, 0.010 \leq$ $\eta^{2} \leq 0.039$ is deemed as a small, $0.039<\eta^{2} \leq 0.11$ a medium, and $0.11<\eta^{2} \leq 0.20$ as the large effect size.

The SPSS software version 22 was used for descriptive and inferential statistics analyses. The level of significance was set at alpha value of .05 .

\section{Research Results}

Based on the preliminary analysis, it was discovered that there was a sufficient conformity to all univariate and multivariate assumptions of MANOVA and MANCOVA. However, the assumption for the equality of covariance matrices was violated in both pre-test (Box's $\mathrm{M}=66.875, F(30,403848.18)=2.185, p<.01)$ and post-test (Box's $\mathrm{M}=341.384, F$ $(30,403848.18)=11.152, p<.01)$. According to Gulbahar and Iwasaki (2007), the violation 
for equality of covariance matrices is common in the analyses of MANOVA and MANCOVA

and this can be easily addressed by using Pillai's trace to evaluate for model significance. Thus, Vol. 78 , No. 4, 2020 the multivariate test statistic used the Pillai's trace to interpret the results of the MANOVA and MANCOVA analyses.

Table 2 shows the descriptive statistics for the students' pre-test and post-test scores on their five sub-scales of trait dimension of scientific creativity.

Table 2

Descriptive statistics of trait dimension of scientific creativity

\begin{tabular}{|c|c|c|c|c|c|c|}
\hline \multirow{2}{*}{$\begin{array}{l}\text { Dependent } \\
\text { Variables }\end{array}$} & \multirow{2}{*}{$\begin{array}{l}\text { Intervention } \\
\text { Group }\end{array}$} & \multirow[b]{2}{*}{$n$} & \multicolumn{2}{|c|}{ Pre-test } & \multicolumn{2}{|c|}{ Post-test } \\
\hline & & & M & $S D$ & M & $S D$ \\
\hline \multirow{4}{*}{ Fluency (F) } & STEM-PjBCL & 120 & 6.83 & 1.71 & 11.68 & 2.31 \\
\hline & $\mathrm{PjBL}$ & 120 & 6.69 & 1.48 & 9.12 & 2.12 \\
\hline & CV & 120 & 6.63 & 1.44 & 8.71 & 1.88 \\
\hline & Total & 360 & 6.71 & 1.55 & 9.84 & 2.48 \\
\hline \multirow{4}{*}{ Originality (0) } & STEM-PjBCL & 120 & 8.74 & 2.91 & 16.43 & 5.57 \\
\hline & $\mathrm{PjBL}$ & 120 & 8.28 & 2.51 & 10.23 & 2.64 \\
\hline & CV & 120 & 8.44 & 2.17 & 9.69 & 2.22 \\
\hline & Total & 360 & 8.49 & 2.55 & 12.17 & 4.86 \\
\hline \multirow{4}{*}{ Elaboration (E) } & STEM-PjBCL & 120 & 11.14 & 2.77 & 19.85 & 5.72 \\
\hline & $\mathrm{PjBL}$ & 120 & 10.27 & 2.42 & 14.13 & 3.45 \\
\hline & CV & 120 & 10.26 & 2.29 & 13.43 & 3.13 \\
\hline & Total & 360 & 10.56 & 2.53 & 15.80 & 5.13 \\
\hline \multirow{4}{*}{ Abstractness of title (A) } & STEM-PjBCL & 120 & 7.81 & 5.18 & 18.48 & 8.09 \\
\hline & $\mathrm{PjBL}$ & 120 & 6.83 & 4.22 & 8.94 & 3.86 \\
\hline & CV & 120 & 7.83 & 3.35 & 8.77 & 2.93 \\
\hline & Total & 360 & 7.49 & 4.33 & 12.06 & 7.08 \\
\hline \multirow{4}{*}{$\begin{array}{l}\text { Resistance to } \\
\text { premature closure (R) }\end{array}$} & STEM-PjBCL & 120 & 7.47 & 1.82 & 14.68 & 4.36 \\
\hline & $\mathrm{PjBL}$ & 120 & 6.95 & 1.75 & 8.48 & 3.14 \\
\hline & CV & 120 & 7.00 & 1.67 & 8.14 & 1.89 \\
\hline & Total & 360 & 7.14 & 1.76 & 10.43 & 4.45 \\
\hline
\end{tabular}

Table 3 shows the findings of MANOVA and followed-up ANOVA analysis. The findings indicated that no significant statistical differences were found across the three groups in each of the pre-tests.

\section{Table 3}

Summary of MANOVA and followed-up ANOVA results on pre-test mean scores

\begin{tabular}{lll}
\hline $\begin{array}{l}\text { MANOVA effect and } \\
\text { dependent variables }\end{array}$ & Multivariate $F$ & Univariate $F$ \\
\hline & $\begin{array}{l}d f=10,706 \\
\text { Pillai's Trace } \\
\text { Group Effect }\end{array}$ & $d f=2.103, p=.58$ \\
& & \\
Pr-F & & $F=2.118, p=.114$ \\
Pr-O & $F=.781, p=.961$ \\
Pr-E & $F=1.149, p=.311$ \\
Pr-A & $F=1.429, p=.106$ \\
Pr-R & $F=.300, p=.974$ \\
\hline
\end{tabular}


Nyet Moi SIEW, Norjanah AMBO. The scientific creativity of fifth graders in a STEM project-based cooperative learning approach

PROBLEMS

OF EDUCATION

IN THE $21^{\text {st }}$ CENTURY

Vol. 78 , No. 4, 2020

There were significant main effects for instructional methods on dependent variables based on the findings from MANCOVA $[F(2,356)=27.537, p<.05]$. Follow-up ANCOVA showed that there were significant main effects of instructional methods on Fluency $[F(2,356)$ $\left.=80.149, p<.05, \eta_{\mathrm{p}}{ }^{2}=.310\right]$, Originality $\left[F(2,356)=129.127, p<.05, \eta_{\mathrm{p}}{ }^{2}=.420\right]$, Elaboration $\left[F(2,356)=73.836, p<.05, \eta_{\mathrm{p}}{ }^{2}=.293,\right]$, Abstractness of Title $[F(2,356)=140.148, p<.05$, $\left.\eta_{\mathrm{p}}{ }^{2}=.441\right]$, Resistance to Premature Closure $\left[F(2,356)=172.029, p<.05, \eta_{\mathrm{p}}{ }^{2}=.491\right]$. A high relationship was found between the instructional method and dependent variables, indicating that $31 \%$ (Fluency), $42 \%$ (Originality), 29.3\% (Elaboration), 44.1\% (Abstractness of Title) and $49.1 \%$ (Resistance to Premature Closure) of the variance obtained was accounted by the instructional methods.

Table 4 shows the findings from further testing using the Post hoc Pair-wise test. It was discovered that students taught with the STEM-PjBCL method outperformed their counterparts in the PjBL group $\left(R_{F}<.05, R_{O}<.05, R_{E}<.05, R_{A}<.05\right.$, and $R_{R}<.05$, respectively), and significantly outperformed their counterparts in the $\mathrm{CV}$ group $\left(R_{F}<.05, R_{O}<.05, R_{E}<.05\right.$, $R_{A}<.05$, and $R_{R}<.05$, respectively) in Fluency, Originality, Elaboration, Abstractness of title, and Resistance to premature closure. However, students in the PjBL method did not show significant better performance as compared to their counterparts in the CV group in Originality, Elaboration, Abstractness of Title, and Resistance to Premature Closure $\left(R_{F}=.326, R_{O}=.490\right.$, $R_{E}=.531, R_{A}=.919$, and $R_{R}=.744$, respectively). Therefore, the research hypothesis was not supported in the comparison between the PjBL and CV methods.

Table 4 also shows a large effect size in the comparison between the STEM-PjBCL and PjBL methods in Fluency (1.2), Originality (1.4), Elaboration (1.2), Abstractness of Title (1.5), and Resistance to Premature Closure (1.6). Additionally, the findings discovered a large effect size for the comparison between STEM-PjBCL and CV in Fluency (1.4), Originality (1.6), Elaboration (1.4), Abstractness of title (1.6), and Resistance to Premature Closure (1.9). Whereas, a very small to small effect size was obtained for comparing the PjBL and CV methods in Fluency (0.2), Originality (0.2), Elaboration (0.2), Abstractness of Title (0.1), and Resistance to Premature Closure (0.1).

Table 4

Summary of post hoc pairwise comparison

\begin{tabular}{|c|c|c|c|c|}
\hline Comparison Group & Mean Difference & $p$ & $\begin{array}{l}\text { Effect } \\
\text { size }\end{array}$ & Interpretation \\
\hline \multicolumn{5}{|c|}{ Fluency } \\
\hline STEM-PjBCL vs PjBL & 2.443 & $<.05$ & 1.2 & Large \\
\hline STEM-PjBCL vs CV & 2.883 & $<.05$ & 1.4 & Large \\
\hline PjBL vs CV & .389 & .326 & 0.2 & Small \\
\hline \multicolumn{5}{|c|}{ Originality } \\
\hline $\begin{array}{l}\text { STEM-PjBCL vs PjBL } \\
\text { STEM-PjBCL vs CV } \\
\text { PjBL vs CV }\end{array}$ & $\begin{array}{l}5.944 \\
6.574 \\
.629\end{array}$ & $\begin{array}{l}<.05 \\
<.05 \\
.490\end{array}$ & $\begin{array}{l}1.4 \\
1.6 \\
0.2\end{array}$ & $\begin{array}{l}\text { Large } \\
\text { Large } \\
\text { Small }\end{array}$ \\
\hline $\begin{array}{l}\text { STEM-PjBCL vs PjBL } \\
\text { STEM-PjBCL vs CV } \\
\text { PjBL vs CV }\end{array}$ & $\begin{array}{l}5.226 \\
5.936 \\
.710\end{array}$ & $\begin{array}{l}<.05 \\
<.05 \\
.531\end{array}$ & $\begin{array}{l}1.2 \\
1.4 \\
0.2\end{array}$ & $\begin{array}{l}\text { Large } \\
\text { Large } \\
\text { Small }\end{array}$ \\
\hline $\begin{array}{l}\text { STEM-PjBCL vs PjBL } \\
\text { STEM-PjBCL vs CV } \\
\text { PjBL vs CV }\end{array}$ & $\begin{array}{ll} & \text { Abstra } \\
9.069 & \\
9.737 & \\
.668 & \end{array}$ & $\begin{array}{l}<.05 \\
<.05 \\
.919\end{array}$ & $\begin{array}{l}1.5 \\
1.6 \\
0.1\end{array}$ & $\begin{array}{l}\text { Large } \\
\text { Large } \\
\text { Very Small }\end{array}$ \\
\hline \multicolumn{5}{|c|}{$\begin{array}{c}.919 \\
.668 \\
\text { Resistance to Premature Closure }\end{array}$} \\
\hline $\begin{array}{l}\text { STEM-PjBCL vs PjBL } \\
\text { STEM-PjBCL vs CV } \\
\text { PiBL vs CV }\end{array}$ & $\begin{array}{l}5.773 \\
6.203 \\
.430\end{array}$ & $\begin{array}{l}<.05 \\
<.05 \\
.744\end{array}$ & $\begin{array}{l}1.6 \\
1.9 \\
0.1\end{array}$ & $\begin{array}{l}\text { Large } \\
\text { Large } \\
\text { Very Small }\end{array}$ \\
\hline
\end{tabular}




\section{Discussion}

Generally, this research findings revealed that fifth graders taught via the STEMPjBCL method performed significantly higher than their counterparts taught via the PjBL and CV method. However, it was also found that fifth graders taught via the PjBL method did not perform significantly higher than their counterparts taught via the CV method in the five sub-scales of trait dimension of scientific creativity namely i) Fluency, ii) Originality, iii) Elaboration, iv) Abstractness of Title, and v) Resistance to Premature Closure. A large effect size of more than 1.0 for comparing the STEM-PjBCL and CV method, and the STEM-PjBCL and PjBL method indicates that the STEM-PjBCL method is the most effective of these three instructional methods in fostering the five sub-scales of trait dimension among fifth graders. In contrast, fifth graders taught via the PjBL method did not outperform those taught via the CV method with a small effect size.

\section{STEM-PjBCL}

As students worked through STEM-PjBCL approach, they were able to experience a wide range of creativity and STEM learning. During an ideation, students were encouraged and guided to think like a scientist, technologist, mathematician, as well as to think like an engineer. They were also engaged to design and sketch a prototype using engineering and technology skills and scientific knowledge. In another moment, they did some calculations for a cost-effective project using mathematical literacy and suitable materials. Over time, they found that STEM-PjBCL activities were interdisciplinary. Most of the time, students learnt to tackle real-world problems from multiple angles using STEM and used materials and tools in different ways to create new technical products. Savery (2015) asserted that real-world problems are often requiring an interdisciplinary approach comprised of unique skillsets from multiple disciplines to develop possible solutions. There was an increased possibility that a bigger number of relevant ideas would be generated by the fifth graders through this learning process. This is in line with Meacham and Emont (1989) who posit that ill structured problems require learners to consider alternative solutions and pursue different procedures for solving the problem. In the ill-structured problem-solving processes, students would ultimately become more creative thinkers. As a result, this led to an increase in the fluency mean scores in the STEM-PjBCL method which exceeded those scores in the PjBL and CV methods.

Similarly, in the STEM-PjBCL method, group members were offered freedom in solving real-world problems with no single right answer. Real world problems engage students to integrate STEM knowledge from mathematics, science, engineering and technology in order to design, create and invent technical products together. In this process, they were engaged in the brainstorming and generating of many new ideas while "putting their heads together". This is in fact a safe and supportive environment in developing many original or unique responses, in line with Sawyer (2003) who stated that people who are engaged in activities together produce a novel outcome. Ramani and Brownell (2014) agreed that children who engage in cooperative problem-solving processes during social play with peers are the key to generate more novel solutions to a problem. Thus, this explains why the fifth graders students in STEM-PjBCL scored significantly higher mean scores in Originality than the students who were taught via PjBL and CV method.

The students taught with the STEM-PjBCL method were assigned to heterogeneous cooperative learning groups. Students from different backgrounds can cultivate a productive interaction among members in a group project (Utaminingtyas et al., 2017). Through productive interactions and communication among group members, students were able to produce technical products using the scientific, technological, engineering and mathematical knowledge and this 
PROBLEMS

OF EDUCATION IN THE $21^{\text {st }}$ CENTURY Vol. 78, No. 4, 2020

638

social process enhanced their elaboration skills. Students were more capable to scaffold their counterparts to refine details, explain, and add more logical details in the existing ideas, which in turn helped them to capture more information for their sketches or creations. This effort indirectly helped less capable students to foster their elaboration skills. This is in line with Vygotsky's (1986) Social Cognitive Theory who argued that children can progress further in their zone of proximal development with the presence of a more competent peer or adult.

Meanwhile, the findings of the study also revealed that fifth graders taught with the STEM-PjBCL method showed a bigger potential in thinking about more abstract titles for their sketches as compared to their counterparts taught with the PjBL and CV methods. While designing and making a group technical product, students worked cooperatively in selecting the best materials and in sketching their best ideas on the worksheet. During this process, students learned to justify their group's suggestions using their own experiences and represented it through the title in the sketch. By engaging in positive peer social learning interactions, students discovered different perspectives and ideas related to a topic (Hurst et al., 2013), which could have indirectly fostered abstract thinking. Interaction among counterparts also increased their ability to capture the essence of the information involved by examining the depth and richness of the title proposed for their sketches. This is supported by Miller (2005) who stated that students' interactions with their environment as well as daily routines have a positive effect on developing abstract thinking. Thus, students in the STEM-PjBCL group were more adept to think of more abstract titles rather than basic titles such as "Floating Seeds", "Mini Ice Box", "Bird Cage", and so on, as generated by their PjBL and CV counterparts.

STEM-PjBCL includes a phase for testing products. During this phase, students learn how to figure out what's working, make sense out of what's failing, and then create a better iteration using STEM knowledge. When students are constantly improving and iterating by considering more options in response to the presented technical products, they encounter a greater increase of Resistance to Premature Closure. Gillies (2003) also agreed that a structured cooperative learning environment is conducive for the development of creative individuals who are open to diverse experiences and integrating novel ideas into one's own experience. As a result, fifth graders who were exposed to the STEM-PjBCL method had significant better performances than their PjBL and CV counterparts in the sub-scales of resistance to premature closure.

\section{$\operatorname{PjBL}$}

However, fifth graders taught in the PjBL method did not have significant better performances as compared to their counterparts in the CV method in the five sub-scales of trait dimension of scientific creativity. The fifth graders who were taught through the PjBL method alone were not explicitly exposed to the STEM and engineering design process. Thus, fifth graders are less likely to apply the mathematics and science knowledge that they had learned and use engineering as a way to solve a problem in order to design and make some types of technical products. According to Bozkurt et al. (2020), students need to acquire scientific, mathematical, and technological skills to solve real-life problems by using engineer-like designs. Students were also less likely to use technology to compare the cost of items and to calculate the total cost. While doing the project, students moderately engaged their Science knowledge about the properties of various local materials to ensure that their technical products would last. Students also had less opportunities to find out how to measure and approximate the size of the technical product, and to calculate whether additional amounts of materials were needed (Mathematics and Engineering). Mayasari et al. (2016) stressed that STEM knowledge is necessary to improve the creativity of the students, in addition to their skills to solve daily problems related to STEM. Ugras (2018) also supports that designed-based STEM activities help students to improve their 
scientific creativity. Similar findings were reported in the literature (Knezek et al., 2013; Sahin et al., 2014; Siew et al., 2015).

In addition, PjBL students were not engaged in Numbered Heads Together cooperative learning activities to become individually accountable to their counterparts in group discussion. Consequently, high-performing students had fewer opportunities to bring out more perspectives in discussion and low-performing counterparts were unlikely to think about several possible ideas to the design and making the prototype. When the discussion showed only several perspectives that resulted in few different answers, the students tended not to consider alternatives to their original thoughts (Siew et al., 2017). As a result, the students' involvement in the PjBL group was less productive in coming up with more diverse ideas about their sketches, which lead them to only state a few basic details without considering other important elements (Elaboration).

Although students in the PjBL group were encouraged to provide ideas on the abstract title, their level of competence was not comparable to those students who were involved in the STEM-PjBCL group. When students were not exposed to STEM, they were unable to draw the essence of the knowledge from different disciplines of STEM in order to create a rich title. As a result, students in the PjBL group were more prone to produce basic titles in their sketches.

In addition, students in the PjBL group were given the freedom to participate in the group project, thus, there was a problem of unequal participation as there were no specific roles allocated to group members. The passive learners only acted as observers who contributed very little to the production of the sketches and technical products. Kagan (1994) argued that when a group does not have the same level of participation from everyone, the group discussion sessions may only exclusively involve the high-performing students. As a result, fifth graders who were taught in the PjBL group are less likely to play an active role in the discussion activities and sharing of ideas. Such a learning environment makes students less receptive to attempts to integrate novel ideas or other's ideas into one's own experience (Resistance to Premature Closure).

In conclusion, without the integration of STEM into the project-based learning in the structured cooperative learning environment, students were unable to generate as many ideas or technical products (fluency) that were unique, detailed, and abstract as their counterparts in the STEM-PjBCL group.

In contrast, the conventional PjBL learning method did not engage students with illstructured problems, STEM and Numbered Heads Together cooperative learning. This method does not allow for a variety of approaches in producing sketches and technical products and holds many students back from demonstrating their strengths to enhance their tract dimensions of scientific creativity. Additionally, this method did not explicitly teach children how to use their fundamental skills and STEM knowledge to reach innovative solutions for real-life problems. Thus, fifth graders in CV only focused on solving well-structured problems without involving their counterparts to assess the viability of alternative solutions to the problem. This is in line with Jonassen (1997) who agreed that well-structured problems "engage the application of a limited number of rules and principles that are organized in a predictive and prescriptive arrangement with well-defined, constrained parameters" (Jonassen, 1997, p. 68). This eventually caused fifth graders to have very little promotive interaction with their team members. As viewed by social interdependence theory, promotive interaction between learners is important for students to encourage and facilitate the work of others through sharing resources, providing help to one another, challenging reasoning and conclusions provided by group members, and taking varying points of view into account (Johnson and Johnson, 2009). As a result, students in the CV group contributed very few original ideas to help one another, 
PROBLEMS

OF EDUCATION

IN THE $21^{\text {st }}$ CENTURY

Vol. 78 , No. 4, 2020

640

Nyet Moi SIEW, Norjanah AMBO. The scientific creativity of fifth graders in a STEM project-based cooperative learning approach

were less fluent in generating and elaborating ideas, less imaginative in producing abstract titles and less open to consider more available information. For these reasons, the fifth graders in the CV group did not promote as much fluency, originality, elaboration of ideas, abstractness of the project title, and had shown less resistance to premature closure as compared to their STEMPjBCL counterparts.

\section{Conclusions}

This research proves that the STEM project-based with NHT cooperative learning approach (STEM-PjBCL) can enhance fifth graders' scientific creativity. Conclusively, fifth graders taught using the STEM-PjBCL method could benefit from the STEM approach to promote their trait dimensions of scientific creativity more effectively, as compared to their counterparts who were taught with the PjBL and CV methods. In other words, providing the students with unstructured group learning environment using $\mathrm{PjBL}$ alone is not enough to effectively foster scientific creativity within a primary school classroom. The STEM approach that associates the disciplines of science, technology, engineering and mathematics with real life problems and well-structured NHT cooperative learning are needed to increase the PjBL's effectiveness. This research shows that the fifth graders' fluency, originality, elaboration of ideas, imagination for novel abstract titles, and resistance to premature closure can be fostered through a carefully structured STEM approach in the teaching and learning of primary science lessons using PjBL and NHT cooperative learning.

This research provided a fundamental proof that engaging fifth graders using the STEMPjBCL method can pave the way for them to show their scientific creativity. Additionally, this research also supports new research evaluating the potential effects of an integrated approach using different instructional methods in fostering scientific creativity among students of different grades.

\section{Acknowledgments}

The researchers would like to express their sincere gratitude to Universiti Malaysia Sabah, Sabah, Malaysia for supporting this research under Grant No. FRG0462-2017.

\section{References}

Ambo, N., \& Siew, N. M. (2017). Development and validation of scientific creativity test through sketches among fifth graders. Sabah Zone Proceedings of National Education Research Seminar, 2017 (pp. 335-345). Tawau Campus Teacher Education Institute.

Bacon, D. R., Stewart, K. A., \& Silver, W. S. (2019). Republication of "Lessons from the best and worst student team experiences: How a teacher can make the difference". Journal of Management Education, 43(5), 550-572. https://doi.org/10.1177/1052562919838523

Bell, T., Urhahne, D., Schanze, S., \& Ploetzner, R. (2010). Collaborative inquiry learning: Models, tools and challenges. International Journal of Science Education, 3(1), 349-377. https://doi.org/10.1080/09500690802582241

Bozkurt Altan, E., Tan, S. (2020). Concepts of creativity in design-based learning in STEM education. International of Journal Technology \& Design Education, 1-27. https://doi.org/10.1007/s10798-020-09569-y

Buck Institute for Education (2020, May 01). What is PBL? PBLWorks. https://www.pblworks.org/whatis-pbl

Campbell, D. T., \& Stanley, J. C. (1963). Experimental and quasi experimental designs for research on teaching. In N. L. Gage (Ed.), Handbook of research on teaching (pp. 171-246). Rand McNally.

Chua, Y. P. 2012. Asas statistik Penyelidikan [Basis research statistics]. McGraw Hill Education.

Cohen, J. (1988). Statistical power analysis for the behavioral sciences. Lawrence Erlbaum Associates. 
Curriculum Development Division. (2014). Primary school standard curriculum. Malaysian Ministry of Education.

Davies, W. M. (2009). Groupwork as a form of assessment: Common problems and recommended solutions. Higher Education, 58, 563-584. https://doi.org/10.1007/s10734-009-9216-y

English, L. D., King, D., \& Smeed, J. (2017). Advancing integrated STEM learning through engineering design: Sixth-grade students' design and construction of earthquake resistant buildings. Journal of Education Research, 110(3), 255-271. https://doi.org/10.1080/00220671.2016.1264053

Gill, J., \& Johnson, P. (2002). Research methods for managers. Sage.

Gillies, R. M. (2003). Structuring cooperative group work in classrooms. International Journal of Educational Research, 39(1), 35-49. https://doi.org/10.1016/S0883-0355(03)00072-7

Grice, J., \& Iwasaki, M. (2007). A truly multivariate approach to MANOVA. Applied Multivariate Research, 3, 199-226. https://psychology.okstate.edu/faculty/jgrice/psyc6813/Grice_Iwasaki_ AMR.pdf

Gulbahar, Y., \& Tinmaz, H. (2006). Implementing project-based learning and E- portfolio assessment in an undergraduate course. Journal of Research on technology in Education, 38(3), 309. https://doi.org/10.1080/15391523.2006.10782462

Hanif, S., Wijaya., A., \& Winarno, N. (2019). Enhancing students' creativity through STEM project-based learning. Journal of Science Learning, 2(2), 50-57. https://doi.org/10.17509/jsl.v2i2.13271.g8451

Hair, F. J., Anderson, E., Tatham, L., \& Black, C. (1998). Multivariate data analysis. $5^{\text {th }}$ Eds. Prentice Hall.

Harel, I., \& Papert, S. (1991). Constructionism. Ablex.

Hassanien, A. (2006). Student experience of group work and group assessment in higher education. Journal of Teaching in Travel \& Tourism, 6(1), 17-39. https://doi.org/10.1300/J172v06n01 02

Henriksen, D. (2014). Full STEAM ahead: Creativity in excellent STEM teaching practices. The STEAM Journal, 1(2), 1-7. https://doi.org/10.5642/steam.20140102.15

Hilton, S., \& Philips, F. (2010). Instructor-assigned and student-selected groups: A view from inside. Issues in Accounting Education, 25(1), 15-33. https://doi.org/10.2308/iace.2010.25.1.15

Holm, M. (2011). Project-based instruction: A review of the literature on effectiveness in pre-kindergarten through $12^{\text {th }}$ Grade classrooms. InSight: Rivier Academic Journal, 7(2), 1-13.

Hu, W., \& Adey, P. (2002). A scientific creativity test for secondary school students. International Journal of Science Education, 24(4), 389-403. https://doi.org/10.1080/09500690110098912

Hurst, B., Wallace, R., \& Nixon, S. B. (2013). The Impact of Social Interaction on Student Learning. Reading Horizons: A Journal of Literacy and Language Arts, 52(4). https://scholarworks.wmich. edu/reading_horizons/vol52/iss $4 / 5$

Johnson, D. W., \& Johnson, R. T. (2009). An educational psychology success story: Social interdependence theory and cooperative learning. Educational Researcher, 38(5), 365-379. https://doi.org/10.3102/0013189X09339057

Jonassen, D. H. (1997). Instructional design models for well-structured and ill-structured problemsolving learning outcomes. Educational Technology Research and Development, 45, 65-94. https://doi.org/10.1007/BF02299613

Kafai, Y., \& Resnick, M. (1996). Constructionism in practice: Designing, thinking and learning in a digital world. Lawrence Erlbaum.

Kagan, S. (1994). Cooperative learning. Kagan Publications.

Kagan. S., \& Kagan, M. (2009). Kagan cooperative learning. Kagan Publishing.

Katz, Lilian. (1994b). The project approach. ERIC Digest. ERIC Clearinghouse on Elementary and Early Childhood Education. https://files.eric.ed.gov/fulltext/ED368509.pdf

Kim, K. H. (2011). The creativity crisis: The decrease in creative thinking scores on the Torrance tests of creative thinking. Creativity Research Journal, 23(4), 285-295. https://doi.org/10.1080/10400419.2011.627805

Knezek, G., Christensen, R., Wood, T. T., \& Periathiruvadi, S. (2013). Impact of environmental power monitoring activities on middle school student perceptions of STEM. Science Education International, 24(1), 98-123.

Massachusetts Department of Elementary and Secondary Education. (2016). 2016 Massachusetts Science and Technology/Engineering Curriculum Framework. http://www.doe.mass.edu/frameworks/ scitech/2016-04.pdf 
Nyet Moi SIEW, Norjanah AMBO. The scientific creativity of fifth graders in a STEM project-based cooperative learning approach

PROBLEMS

OF EDUCATION IN THE $21^{\text {st }}$ CENTURY Vol. 78, No. 4, 2020

642

Mayasari, T., Kadarohman, A., Rusdiana, D., \& Kaniawati, I. (2016). Exploration of student's creativity by integrating STEM knowledge into creative products. AIP Conference Proceedings, 1708. 080005. https://doi.org/10.1063/1.4941191

Maulana, R. T. (2014). Numbered heads together (NHT): An endeavour to improve student's scientific creativity and mastery concept in learning global warming. Universitas Pendidikan Indonesia Repository. Upi.Edu Perpustakaan. Upi.Edu.

Meacham, J. A., \& Emont, N. M. (1989). The interpersonal basis of everyday problem solving. In J. D. Sinnott (Ed.), Everyday problem solving: Theory and applications (pp. 7-23). Praeger.

Miller, S.A. (2005) Reflections on kindergarten giving young children what they deserve. Childhood Education, 81(5), 256-260, http://dx.doi.org/10.1080/00094056.2005.10521302

Mukhopadhyay, R., \& Sen, M. K. (2013). Scientific creativity - a new emerging field of research: Some considerations. International Journal of Education and Psychological Research, 2(1), 1-9.

Plesk, P. E. (1997). Creativity, innovation, and quality. ASQC Quality Press.

Ramani, G. B., \& Brownell, C. A. (2014). Preschoolers' cooperative problem solving: Integrating play and problem solving. Journal of Early Childhood Research, 12(1), 92108. https://doi.org/10.1177/1476718X13498337

Russell, M. (2010). The formation of effective work groups within an FE classroom. Research in Postcompulsory Education, 15(2), 205-221. https://doi.org/10.1080/13596741003790765

Sahin, A., Ayar, M., \& Adiguzel, T. (2014). STEM related after-school program activities and associated outcomes on student learning. Educational Sciences: Theory and Practice, 14, 309-322. https://doi.org/10.12738/estp.2014.1.1876

Sak, U., \& Ayas, M. B. (2013). Creative scientific ability test (C-SAT): A new measure of scientific Creativity, Psychological Test and Assessment Modelling, 55(3), 316-329.

Savery, J. R. (2015). “Overview of problem-based learning: Definitions and distinctions.” In C. E. HmeloSilver, H. Leary, \& A. Walker (Eds.), Essential readings in problem-based learning (pp. 5-15). Purdue University Press. https://doi.org/10.7771/1541-5015.1002

Sawyer, K. (2003). Emergence in creativity and development. In K. Sawyer (Eds.), Creativity and development (pp. 12-60). Oxford University Press.

Seel N. M. (2012) Experimental and quasi-experimental designs for research on learning. In: Seel N.M. (Eds), Encyclopedia of the sciences of learning (pp. 1223-1229). Springer. https://doi.org/10.1007/978-1-4419-1428-6_716

Shriki, A. (2013). A model for assessing the development of students' creativity in the context of problem posing. Creative Education, 4(7), 430-439. https://doi.org/10.4236/ce.2013.47062

Siew, N. M., Ambo, N. (2018). Development and evaluation of an integrated project-based and STEM teaching and learning module on enhancing scientific creativity among fifth graders. Journal of Baltic Science Education, 17(6), 1017-1033. https://doi.org/10.33225/jbse/18.17.1017

Siew, N. M., \& Chin, M. K. (2018). Design, development and evaluation of a cooperative problem-based learning module on scientific creativity of pre-schoolers. Journal of Baltic Science Education, 17(2), 215-228. http://dx.doi.org/10.3402/rlts 2010.19186

Siew, N. M., Amir, N., \& Chong, C. L. (2015). The perceptions of pre-service and in-service teachers regarding a STEM project-based learning approach to teaching science. SpringerPlus, 4(1), 1-20. https://doi.org/10.1186/2193-1801-4-8

Siew, N. M., Chin, M. K., \& Sombuling, A. (2017). The effects of problem-based learning with cooperative learning on preschoolers' scientific creativity. Journal of Baltic Science Education, 16(1), 100112. http://www.scientiasocialis.lt/jbse/files/pdf/vol16/100-112.Siew_JBSE_Vol.16_No.1.pdf

Smith, G. J. W., \& Carlsson, I. (1983). Creativity in early and middle school years. International Journal of Behavioral Development, 6, 167-195. https://doi.org/10.1177/016502548300600204

Steen, M. (2013). Virtues in participatory design: Cooperation, curiosity, creativity, empowerment, and reflexivity. Science and Engineering Ethics, 19 (3), 945-62. https://doi.org/10.1007/s11948-012-9380-9

Storer, T. (2018). The effect of project-based learning on the creativity of elementary students (Accession No. 10829033) [Doctoral dissertation, Wilkes University]. ProQuest.

Stylianidou, F., Glauert, E., Rossis, D., Compton, A., Cremin, T., Craft, A., \& Havu-Nuutinen, S. (2018). Fostering inquiry and creativity in early years STEM education: Policy recommendations from the creative little scientist's project. European Journal of STEM Education, 3(3), 15. https://doi.org/10.20897/ejsteme/3875 
Tawau District Education Office. (2017). UPSR science achievement data for 2015-2017. Science and Mathematics Unit, Tawau District Education Office, Sabah.

Torrance, E. P., Ball, O. E., \& Safter, H. T. (2008). Torrance test of creative thinking: Streamlined scoring guide for figural forms $A$ and $B$. Scholastic Testing Service.

Tytler, R., Swanson, D. M., \& Appelbaum, P. (2015). Subject matters of science, technology, engineering, and mathematics. In M. F. He, B. D. Schultz, \& W. H. Schubert (Eds.), The Sage guide to curriculum in education (pp. 27-35). Sage.

Ugras, M. (2018). The effect of STEM activities on STEM attitudes, scientific creativity and motivation beliefs of the students and their views on STEM education. International Online Journal of Educational Sciences, 10(5), 165-182. https://doi.org/10.15345/iojes.2018.05.012

Utaminingtyas, K. T., Herdianti, R. E., Fitria, I. H., \& Prayitno, A. (2017). Small groups: Student productive interactions in learning cooperative (Case study of mathematics learning at junior high school in Pakis, Malang). Educational Process: International Journal, 6(2), 37-42. https://doi.org/10.22521/edupij.2017.62.3

Voss, J. F., \& Post, T. A. (1988). On the solving of ill-structured problems. In M. T. H. Chi, R. Glaser, \& M. J. Farr (Eds.) The nature of expertise (pp. 261-285). Lawrence Erlbaum.

Vygotsky, L.S. (1986). Thought and language. MIT Press.

White, B. Y., \& Frederiksen, J. R. (1998). Inquiry, modelling, and metacognition: Making science accessible to all students. Cognition and Instruction, 16(1), 3-118. https://doi.org/10.1207/s1532690xci1601_2

Received: May 02, 2020

Accepted: August 03, 2020

Cite as: Siew, N. M., \& Ambo, N. (2020). The scientific creativity of fifth graders in a STEM project-based cooperative learning approach. Problems of Education in the $21^{\text {st }}$ Century, 78(4), 627-643. https://doi.org/10.33225/pec/20.78.627

\begin{tabular}{|ll}
$\begin{array}{l}\text { Nyet Moi Siew } \\
\text { (Corresponding author) }\end{array}$ & $\begin{array}{l}\text { PhD, Senior Lecturer, Faculty of Psychology and Education, University Malaysia } \\
\text { Sabah, Jalan UMS, 88400, Kota Kinabalu, Sabah, Malaysia. } \\
\text { E-mail: snyetmoi@yahoo.com }\end{array}$ \\
\hline Norjanah Ambo & $\begin{array}{l}\text { PhD, Head of Science Panel, St. Patrick Primary School, Post Box 510, 91008, } \\
\text { Tawau, Sabah, Malaysia. } \\
\text { E-mail: norjanah5944@gmail.com }\end{array}$
\end{tabular}

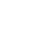

